\title{
EGFR Antagonist Hemay022
}

National Cancer Institute

\section{Source}

National Cancer Institute. EGFR Antagonist Hemay022. NCI Thesaurus. Code C123722.

An orally available, irreversible inhibitor of epidermal growth factor receptor (EGFR), with potential antineoplastic activity. Upon oral administration, Hemay022 covalently binds to and inhibits the activity of EGFR, thereby preventing EGFR-mediated signaling. This may both induce cell death and inhibit tumor growth in EGFR-overexpressing tumor cells. EGFR, a receptor tyrosine kinase mutated in many tumor cell types, plays a key role in tumor cell proliferation and tumor vascularization. 